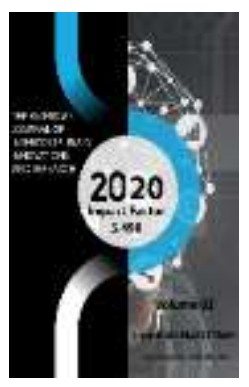

\title{
A New Approach To The Work Of Muhammad Aminkhoja Muqimi (1850-1903)
}

\author{
Kuldosh Pardaev \\ Doctor Of Philological Sciences, Associate Professor, Tashkent State University Of Uzbek \\ Language And Literature Named After Alisher Navoi, Uzbekistan
}

Journal Website: http://usajournalshub.c om/index,php/tajiir

Copyright: Original content from this work may be used under the terms of the creative commons attributes 4.0 licence.

\section{ABSTRACT}

When comparing the text of the works of the enlightened artist Muhammad Aminkhoja Muqimi, who lived and worked in the literary environment of Kokand in the late XIX - early XX centuries, it became clear that the text of most poems does not correspond to the original. Because of the demands of the Soviet ideology, the poet's poems on religious and mystical themes were edited and shortened. Strong socially critical bytes and paragraphs in the text of the comic works were also omitted. As a result, the edited works were misinterpreted. Muqimi's works left in manuscript sources are important in the study of the poet's worldview, his attitude to social reality, his literary and aesthetic world.

\section{KEYWORDS}

Satire, publication, poet, verse, verse, literary environment, style, interpretation, editing, manuscript, ghazel, poem, Turkestan, muhammas.

\section{INTRODUCTION}

A special place in the history of Uzbek literature belongs to the heritage of artists who grew up in the literary environment of Kokand. The works of Muhammad Aminkhoja Muqimi, a brilliant representative of this literary environment, have always been in the spotlight of experts.

The poet's works are not arranged in the Dewanian order. However, in the early twentieth century, a collection of poems called 
"Dewan" was published in lithography [University of Oriental Studies of the Republic of Uzbekistan 10119-309-318-236]. However, all four collections were arranged without complying with the requirements for creating a cabinet. Therefore, these collections can be considered not as "Dewan", but as a collection of poems.

It is known that a lot of research has been done on the poet's works. Unfortunately, Muqimi's works were interpreted one-sidedly in accordance with the requirements of the Soviet ideology. As a result, the poet's poetic legacy was removed from its essence. That is, his works were edited, shortened, and remained in the sources. This, in turn, necessitates an objective and objective study of the poet's literary heritage on the basis of new criteria. Muqimi's works have been preserved in various manuscripts and lithographs, in the notebooks of artists, in the collections of amateur writers, in some pieces of paper in the hands of different people. It should be noted that Professor G. Karimov's contribution to the collection and publication of the poet's works is great. He published Muqimi's "Collection of Works" a total of four times (1958-1960-1973-1974). Unfortunately, in these publications, Muqimi's work was not published in full and in perfect form due to the strong pressure of the communist ideology.

In the following years, scientific research was conducted on the manuscripts of Muqimi's works. In particular, some poems that were not included in the latest edition of the poet's works in the Soviet era [Karimov1974] were brought to the attention of the general public. In particular, the research of literary critic 0 . Juraboev on the manuscripts of Muqimi's poems is commendable [Juraboev Literature and Art of Uzbekistan, 19993; Sino, 2007. №28; Tafakkur, 2003; Literary Mirror, 2000; Language and Literature Education, 2001]. Also, in 1997, with the help of literary critic A. Madaminov, the collection "New Bayoz" was published. Literary critic A.Turdialiev in 2010 published the poet's collections "Between the Gardens", E.Ochilov in 2009 "My heart is in you", K. Pardaev in 2019 "Muqimi that we don't know".

\section{THE MAIN FINDINGS AND RESULTS}

According to the ideology of the Soviet period, the following aspects of the poet's work were deliberately distorted in the research of local scholars. First, most of the poet's poetic works in the religious-mystical spirit remained unpublished. Second, portraying Muqimi as a wealthy, merchant, anti-judge was identified as a priority for research. Third, Muqimi's approach to "palace of literature" and its traditions was misinterpreted, and signs of class struggle were sought from them.

Like the poet's lyrical poems of various genres, "Property of Regret", "Comic Bekturboy", "Dar mardumi Oqjar batariqi muhammas", "Dar mazammati zamona", "A poem recited by a Muqimi poet in honor of a rich man from Khojand", "Urug”, “Veksil”, “Dar mazammati qurbaqa", "Travelogue" This is evidenced by the fact that his comics on many socio-political topics, such as In particular, the poem "Property of Regret" in the muhammas genre has 6 points in the collection of Muqimi's works, and 8 points in the original. Two verses have been deliberately omitted. In addition, the verses in almost all verses of the muhammas have been edited. It has since been included in current publications. As a result, the poet's critical view of the socio-political events of the period, in general, hides the poet's spiritual world. We see a similar situation in the first two verses of the muhammad:

In current editions:

The owner of our property of regret is dead, Shari'a law is dead in the hands of judges, In fact, [Madaminov 1997,34]: 
Regret, the ruler of the religion of Islam, the people of the dead,

The Shari'a mirror is filthy, the dust is dead,

Apparently, the poem has been completely reversed. As a result, the poet's criticism was not directed at the colonialists, but at the clergy, judges and the rich. In fact, it is well known that this is not the purpose of the poet. In these verses, the poet says, "The mirror of the Shari'ah is the dust of disbelief, and the dust is dead". The fact that our religion, our Shari'a has been violated by the colonialists, and as a result the people are moving away from the Shari'a, and that the nation as a whole has fallen into such a tragic situation, into a colonial vortex, is the reason for its justified protest.

We see such a one-sided approach to Muqimi's work in the interpretation of the poet's poetic works on a variety of socio-political themes. This is seen in portraying Muqimi as a rich man, a merchant, a judge, and a religious leader. For example, the poet's interpretation of the work "Travelogue" is proof of this. Item 8 of the "From Kokand to Shohimardon" part of the "Travelogue" is given in the current editions of all Muqimi's works as follows:

Then Ghazi said,

Both the mufti and the judge said,

The whole country said dissatisfied,

The murder was painful.

Literary critic $\mathrm{H}$. Yakubov first wrote about the interpretation of this verse: "From here the poet goes to Durmancha. This place will not be left behind by Jesus. Sooner or later, he drank poppy, got drunk and took several positions. "[Yakubov1953, 99]. A.Abdugafurov's opinion is the same: The tyranny of officials in all positions in the village, "harassment", The great social content of "Yurt", such as "dissatisfaction", is directly expressed in the following verse: "Abdugafurov 1976, 65].
Professor G. Karimov elaborates on the interpretation of this verse: "The governor of the village of Durmancha He will not escape the criticism of Muqimi. Therefore, a man named Ghazi, who was the governor of the volost in Durmancha, was famous for his cruelty and was hated by the people". [Karimov1987, 121].

Apparently, the opinions of almost permanent scholars are the same. In any case, judges, muftis, pilgrims should be treated negatively. We now cite the original clause [6352, p. 181] of this clause:

Then this pilgrim said,

Both the mufti and the judge said,

Everyone in the country agreed,

The poor was harmless.

In general, from the point of view of the demand of the period, all the verses of the band have been edited. As a result, the author's truthful statements about the mufti, pilgrims and judges turned out to be false, and the text was completely removed from the original. In fact, the image of Ghazi itself does not appear in this paragraph.

We see the same situation in the interpretation of Muqimi's humorous work entitled "A poem recited by a Muqimi poet in honor of a rich man from Khojand" published in the "Turkistan Province Newspaper" on January 15, 1903, No. 2. For some reason, in all Muqimi's works, the title of the poem is "The story of the blind Ashurboy Haji". The 2nd, 7th, and 15 th verses of the poem are given in the edition of Muqimi's works as follows:

Hear the story from Ashurboy.

Is it famous in Fergana?

They said, "If you are rich, move".

Ashur is blind and unstable.

Speak more slowly, I am Ashurboy. 
I'm running away, waiting for you.

We read these verses in the "Turkestan regional newspaper as follows":

Hear the story of the rich man,

Is it famous in Fergana?

They said, "If you are rich, move".

In the end, the shackles hurt.

Speak more slowly, I'm not so-and-so.

I'm running away, waiting for you.

Apparently, there is no image of Ashurboy anywhere. The verses of the poem have been edited and modified by the publishers. After that, the comic poem was entitled "The story of the blind Ashurboy haji". According to the ideology of the Soviet period, verse 26 of the poem was rewritten as follows:

Insulted people mold,

Find the rich word and pay great attention to it.

Literary critic A. Abdugafurov wrote about the byte: "There is another byte in this satire that is especially noteworthy. In it, the poet clearly points to one of the main reasons why the "rich word" finds "great attention" - money, the decisive role of gold in that system. Ashurboy Haji uses "nihoniy" gold and silver ("siymu zar") "like water" and bribes all officials to wash the "dust". [Abdugafurov1976,14]. The opinion of other settlers is in line with this. In fact, the byte in the Turkestan regional newspaper was as follows:

Eshan stayed and blamed the duke,

This man is a merchant to shame.

It should be noted that poetic works with such edits and rewritten verses are often found in the edition of Muqimi works.

A similar situation can be observed in the example of the poet's poem on a socio-political theme entitled "Dar mazammati zamona".
Unfortunately, the text of the poem was in the form of 10 bytes in the conversion copies of Muqimi's works, leaving seven bytes. This led to the concealment of the poet's critical view of the tsarist colony. For example, the 2 nd and 3rd stanzas of the poem, which have been omitted from the editions, are as follows in Muqimi's manuscript No. 1325 (120a):

Circassians, redheads, Armenians in our city,

Muslims have become the eyes of the good.

Ahmadjan stood up as a merchant,

Shijoatdin's body became more and more hairy.

The study of the poet's worldview, his attitude to reality, and the world of artistic and aesthetic thinking in general, is aided by a series of works preserved in sources unknown to the public.

\section{DISCUSSIONS AND RESULTS}

Further research shows that such interpretations of the work of Muhammad Aminkhoja Muqimi are unfounded. It is known that the history of Uzbek literature cannot be separated from "palace of literature". The works of such outstanding representatives of the Uzbek art of speech as Yusuf Khos Hajib, Alisher Navoi, Munis, Ogahi, Uvaysi, Nodira were directly connected with the palace atmosphere. [Kobilova 2007, 44].

As Professor N. Jumakhoja noted: "Palace literature, as we have been told, does not look like a very limited and strange property. It is also difficult, if not impossible, to study this literature from the heart of a single national literature. It is not a matter of studying the literature of the palace and the works of its representatives in all periods of history in one or two articles or books.

In this regard, there is a need to focus on the work of Muqimi and Amir. In Muqimi's poetry 
one can find many works influenced by Amir's work and made nazira and tahmis. Including,

Amir:

Let me tell you a lesson,

Pray from us to the unfaithful [Amir Dewan, 1972, 87].

Muqimi:

Let me tell you a lesson,

Maybe he is talking about a flower [Karimov 1974, 43].

Apparently, Muqimi repeated the first verse of Amir's ghazal and created the art of "tazmin". Muqimi's ghazal is in complete harmony with Amir's ghazal with both content and artistic image. It is known from such ghazals that from the very beginning of Muqimi's work he tried to be as close as possible to the work of his predecessors, to acquire fluency in them.

Muqimi's writings on religious and mystical works are still known today. During the Soviet era, these aspects of the poet's work were ignored. In some cases, these works were interpreted in a way that contradicted their essence, and opinions were expressed that were inconsistent with the poet's spiritual world. This can be seen in the research of $\mathrm{H}$. Zarifov, A. Olimjanov, G. Gulom, H. Vahidov, O. Sharofitdinov, A. Abdugafurov, G. Karimov. In particular, H.Vakhidov writes: "According to Islam, every Muslim who performs Hajj is innocent, respectable and honorable, but according to Muqimi, Hajj does not purify a person from sin and morality, but uses his religious feelings to plunder them into the mire of robbery, superstition and fanaticism. Muqimi saw many flaws in his prayers ... Muqimi turned to his lover and asked him to repent of the ascetic who denied human love:

The altar of your eyebrows,

Repent of the asceticism of so many years.
This is how Muqimi exposes Sufism. [Vohidov 1959, 82]. Unfortunately, it is impossible for a poet like Muqimi to be critical of religious principles, especially fasting, pilgrimage, and worship. E. Ochilov, a literary critic, commented on this verse: "It is impossible to separate this verse from mysticism and interpret it. It is known that in mystical literature, a hermit is described as a person who is ignorant of love and enlightenment. He only wants to attain the bliss of paradise through obedience. The goal of the Sufi is Allah Himself: he has no love of heaven and no fear of hell. If God shows his beauty, hell is better for him than heaven, but if he does not have divine grace, heaven is worse than hell. That is why he looks at the image and says that there is no fire in the heart of the ascetic, so that he may go through a thousand years of asceticism and enter the song of love". [Ochilov 2009, 32].

\section{CONCLUSION}

As a result of the editing of Muqimi's works, many textual differences appeared in the editions of the poet's works. This also had a serious impact on the interpretation of the work. The fact that Muqimi's work "Travelogue" is interpreted at a distance from its essence, the text of the comic book Property of Regret" is edited, the omitted verses from the current editions allow us to think anew, to draw important generalizations. It should be noted that works such as the rewritten poem "Hoqandlik is a poem told by a Muqimi poet in honor of a rich man" are often found in the Muqimi works. Although the poet's newly identified ghazals and muhammas on religious-mystical themes are essentially devoted to the artistic interpretation of religious-mystical ideas, the poet has absorbed into the content of his poems such ideas as the source of oppression and heresy, the glorification of justice. These works show that the Soviet-era research on Muqimi's worldview, the scale of the poet's creative legacy, is unfounded. 
Numerous sources that provide information about Muqimi encourage a deeper reflection on the creative personality and worldview. Therefore, it is necessary to study the newly discovered works of the poet. The period of permanent residence is some period rich in many social contradictions in the history of our Motherland. In this regard, the analysis of the poet's newly discovered poems in the study of the literary-aesthetic world, the environment and society has scientific value.

\section{REFERENCES}

1. University of Oriental Studies of the Academy of Sciences of the Republic of Uzbekistan, lithography. №10119; №309; 18318; №236

2. Karimov Gulom. (1974). Muqimi. Works. Tashkent: Literature and art.

3. Juraboev Otabek. (1999). "I Didn't Find Mercy" Art of Literature Uzbekistan. 9. "Persian poems in Muqimi's manuscripts". Sino, 2003. Muqimi's "Cho'ntak Bayozi". Guliston, 2.

4. Madaminov Ahmadjon. (1997). "New Bayoz". Tashkent: Sharq.

5. Yakubov Homil. (1953). "Democratic poet Muqimi”. Eastern star. 9.

6. Abdugafurov Abdurashid. (1976). Muqimi satire. - Tashkent. Fan.

7. Karimov Gulom. (1987). History of Uzbek literature. The third book. - Tashkent. Teacher.

8. Manuscript bayoz. 6352.

9. Abdugafurov Abdurashid. (1976). Muqimi satire. - Tashkent. Fan.

10. Kobilova Zebo. (2007) "Amir and his literary activity". - Tashkent. Candidate of Philological Sciences. Diss.

11. Jumakhoja Nusratullo. (1995). "Feruz is the patron of culture and art". - Tashkent. Fan.

12. Qodirova Mahbuba. (1972). Amir. Dewan. Tashkent. Fan.

13. Karimov Gulom. (1974) Muqimi. Works. Tashkent. Literature and art.
14. Vohidov Hoshim. (1959) "Socio-political views of Furkat and Muqimi". Tashkent: Uzdavnashr.

15. Ochilov Ergash. (2009) "My heart is in you”. - Tashkent. Sharq. 